\title{
A Pilot Study to Examine the Management of Asymptomatic Hyperparathyroidism in Japanese Patients in Accordance with the Guidelines for Asymptomatic PHPT Proposed at the Third International Workshop in 2008
}

\author{
Atsushi Ogo, Yuka Sakaki, Ryoko Saito, Ryuichi Sakamoto and Yuka Matoba
}

\begin{abstract}
Objective The treatment for asymptomatic primary hyperparathyroidism (PHPT) remains controversial. In 2008, the Third International Workshop on the Management of Asymptomatic PHPT proposed a set of guidelines for the management of asymptomatic PHPT. We therefore evaluated the application of the Workshop recommendations in Japanese patients with asymptomatic PHPT.

Methods We analyzed each parameter of the guidelines in 87 Japanese patients with asymptomatic PHPT who underwent methoxy-isobutyl-isonitrile (MIBI) scintigraphy.

Results Fewer than $10 \%$ of the patients were less than 50 years of age. The bone mineral density T-score was below $-2.5 \mathrm{SD}$ in 20 women (46.5\% of all women analyzed) and in none of the men. The eGFR was $<60 \mathrm{~mL} / \mathrm{min} / 1.73 \mathrm{~m}^{2}$ in 17 patients. A majority of patients (43) satisfied only one parameter, while 25 patients satisfied none of the parameters. Furthermore, the MIBI-positive and surgically treated patients tended to satisfy a larger number of the parameters. The Workshop criteria and levels of PTH, daily Ca excretion, serum ALP and 1,25(OH)2 Vitamin D were further analyzed in relation to the findings of MIBI scans, and almost all of the parameters were found to be significantly correlated with the results of the MIBI studies.

Conclusion Our results suggest the need to reassess the Workshop guidelines for the treatment of hyperparathyroidism in Japanese patients. It is desirable that MIBI scintigraphy be performed whenever possible, as this modality is anticipated to play an important role in determining whether or not surgery is appropriate.
\end{abstract}

Key words: asymptomatic, hyperparathyroidism, Japanese, guidelines

(Intern Med 53: 1749-1754, 2014)

(DOI: 10.2169/internalmedicine.53.2133)

\section{Introduction}

The improved availability of serum calcium (Ca) and parathyroid hormone measurement and advances in diagnostic imaging have increased the rate of detection of asymptomatic primary hyperparathyroidism (PHPT) in Japan. Resection of the affected tissue is the only definitive treatment for PHPT. However, there is controversy over whether and how aggressively to treat asymptomatic PHPT, which accounts for more than half of all PHPT cases. A consensus has been reached regarding surgical treatment for symptomatic PHPT, i.e., patients with osteoporosis, urinary tract stones and other complications, and, in 1990, a statement on the diagnosis and treatment of asymptomatic PHPT was issued by the National Institutes of Health (NIH) (1). In 2002, the statement was updated to include revisions of the surgical indications and methods for evaluating bone mineral density (BMD) and parameters of hypercalcemia (2). In 2008, several additional changes were made to the statement, and another set of guidelines for the treatment of asymptomatic PHPT was proposed $(3,4)$. The present investigation, which was conducted as a pilot study, was designed to analyze each parameter adopted in the proposed 2008 revision of the Third International Workshop guidelines for the management of asymptomatic PHPT in addition to the levels of PTH, daily 


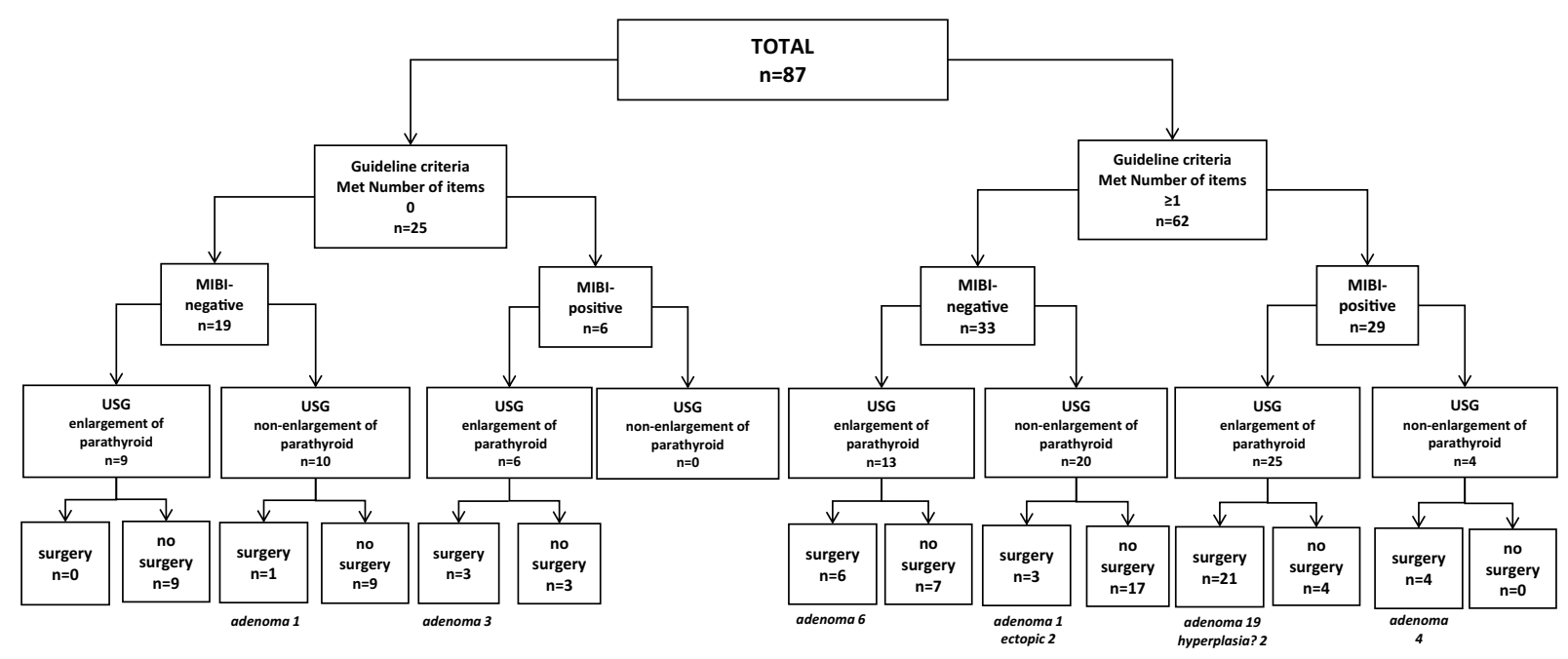

Figure. A flow diagram illustrating the baseline characteristics and outcomes of the 87 patients with asymptomatic PHPT

Ca excretion, serum ALP and 1,25(OH)2 Vitamin D in 87 asymptomatic patients who underwent methoxy-isobutylisonitrile (MIBI) scintigraphy and to compare these parameters between the MIBI-positive and -negative patients and between the patients who did and did not undergo surgical resection of the affected parathyroid, with the goal of evaluating strategies for treating asymptomatic PHPT in Japanese patients.

\section{Materials and Methods}

\section{Subjects}

This study involved 87 patients with asymptomatic PHPT who underwent MIBI scintigraphy to localize the affected area between April 2003 and March 2012 (22 men and 65 women) at a single center. These patients had consulted other clinics or departments regarding hypercalcemia (and elevated PTH); however, detailed examinations were initiated at our department. MIBI scintigraphy was performed using a Siemens Signature gamma camera with a lowenergy high-resolution collimator. Twenty minutes after the intravenous injection of $370 \mathrm{MBq}{ }^{99 \mathrm{~m}} \mathrm{Tc}$ methoxy-isobutylisonitrile, early static images were obtained with an acquisition time of 10 minutes. Although it is difficult to clearly diagnose asymptomatic PHPT, the 87 patients had no clinical profiles, including symptoms of hypercalcemia, kidney stones, overt bone disease or specific neuromuscular dysfunction. Although the bone mineral content of the lumbar spine was measured in all patients, the subjects generally did not undergo simple radiography of the hands; therefore, it was not clear whether osteitis fibrosa or subperiosteal fractures were present.

According to the guidelines of the Third International Workshop on the Management of Asymptomatic PHPT (2008) (4), surgery is recommended for patients meeting any of the surgical criteria. However, management decisions should take into account patient preferences and the pres- ence of coexisting conditions (5). Therefore, we adequately explained the guidelines, results of MIBI scintigraphy and ultrasonography, possible complications, the coexistence of other symptoms and the risks of the operation to each patient and ultimately gave top priority to patient preference.

The study was approved by the Ethics Committee of Kyushu Medical Center. All participants provided their written informed consent.

\section{Data collection}

Data, including gender, age, the albumin-adjusted serum Ca level (BioMajesty, Japan Electron Optics Laboratory, Tokyo, Japan, normal: 8.7-10.3 $\mathrm{mg} / \mathrm{dL})$, the estimated glomerular filtration rate (eGFR), BMD (portion of the lumbar vertebra, T-score: SD) quantified using Dual Energy Xray Absorptiometry (DXA; HOLOGIC Discovery S1 Bone Densitometer, Hologic, Bedford, USA), fracture history, the intact PTH level (The Elecsys PTH assay, Roche Diagnostics, Indianapolis, USA, Normal 10-65 pg/mL), daily Ca excretion (BioMajesty, Normal: 0.1-0.3 g/day), the serum ALP level (BioMajesty, Normal: 115-359 IU/L) and the $1,25(\mathrm{OH})_{2}$ Vitamin D level (The IDS 1,25-Dihydroxy Vitamin D RIA kit, Boldon, Tyne and Wear, United Kingdom, Normal: 20.0-60.0 pg/mL), were collected for further analyses. The study group included 35 patients (seven men and 28 women) with abnormal radioisotope accumulation on MIBI scintigraphy and 38 patients (nine men and 29 women) who had undergone surgical resection of parathyroid tissue believed to be responsible for asymptomatic PHPT.

\section{Results}

Figure presents a flow diagram illustrating the baseline characteristics and outcomes of the 87 patients with asymptomatic PHPT. Twenty-five patients met none of the criteria in the guidelines and 62 fulfilled at least one criterion. Of the patients meeting none of the criteria, four opted to have 
Table 1. Baseline Characteristics of Asymptomatic Hyperparathyroidism Patients

\begin{tabular}{cccccc}
\hline & Age (years) & $\begin{array}{c}\text { Serum Ca } \\
(\mathrm{mg} / \mathrm{dL})\end{array}$ & $\begin{array}{c}\text { eGFR } \\
\left(\mathrm{mL} / \mathrm{min} / 1.73 \mathrm{~m}^{2}\right)\end{array}$ & BMD T-score (SD) & $\begin{array}{c}\text { History of } \\
\text { fracture }\end{array}$ \\
\hline Men & $61.6 \pm 13.9$ & $11.0 \pm 1.0$ & $74.9 \pm 24.9$ & $0.04 \pm 1.5$ & $\mathrm{n}=2$ \\
$\mathrm{n}=22$ & $(\mathrm{n}=22)$ & $(\mathrm{n}=22)$ & $(\mathrm{n}=22)$ & $(\mathrm{n}=14)$ & \\
Women & $65.1 \pm 10.7$ & $11.1 \pm 1.1$ & $81.6 \pm 27.3$ & $-2.4 \pm 1.3$ & $\mathrm{n}=11$ \\
$\mathrm{n}=65$ & $(\mathrm{n}=65)$ & $(\mathrm{n}=65)$ & $(\mathrm{n}=64)$ & $-1.8 \pm 1.7$ & $\mathrm{n}=13$ \\
TOTAL & $64.2 \pm 11.6$ & $11.0 \pm 1.1$ & $79.9 \pm 26.7$ & $(\mathrm{n}=57)$ & $\mathrm{p}=0.502 * *$ \\
$\mathrm{n}=87$ & $(\mathrm{n}=87)$ & $(\mathrm{n}=87)$ & $(\mathrm{n}=86)$ & $\mathrm{p}=0.835^{*}$ & \\
$\mathrm{p}$ value & $\mathrm{p}=0.218^{*}$ & $\mathrm{p}=0.804 *$ & $\mathrm{p}=0.308^{*}$ & & $(\mathrm{mean} \pm \mathrm{SD})$ \\
Men vs. Women & & &
\end{tabular}

Table 2. Number of Cases Corresponding to Each Criterion of the Guideline (2008)

\begin{tabular}{lccccc}
\hline Number & Age (years) & $\begin{array}{c}\text { Serum Ca } \\
(\mathrm{mg} / \mathrm{dL})\end{array}$ & $\begin{array}{c}\text { eGFR } \\
\left(\mathrm{mL} / \mathrm{min} / 1.73 \mathrm{~m}^{2}\right)\end{array}$ & BMD T-score (SD) & Fracture History \\
\hline Criteria & $<50$ & $\leq 11.4$ & $<60$ & $<-2.5$ & + \\
\hline Men & $\mathrm{n}=2$ & $\mathrm{n}=9$ & $\mathrm{n}=6$ & $\mathrm{n}=0$ & $\mathrm{n}=2$ \\
$\mathrm{n}=22$ & $*(1)$ & $*(5)$ & $*(1)$ & $*(0)$ & $*(1)$ \\
& $* *(1)$ & $* *(6)$ & $* *(2)$ & $* *(0)$ & $* *(1)$ \\
Women & $\mathrm{n}=5$ & $\mathrm{n}=20$ & $\mathrm{n}=11$ & $\mathrm{n}=20$ & $\mathrm{n}=11$ \\
$\mathrm{n}=65$ & $*(2)$ & $*(12)$ & $*(2)$ & $*(9)$ & $*(8)$ \\
& $* *(3)$ & $* *(18)$ & $* *(5)$ & $\mathrm{n}=20$ & $* *(7)$ \\
TOTAL & $\mathrm{n}=7$ & $\mathrm{n}=29$ & $\mathrm{n}=17$ & $*(9)$ & $\mathrm{n}=13$ \\
$\mathrm{n}=87$ & $*(3)$ & $*(17)$ & $*(3)$ & $* *(9)$ & $*(9)$ \\
& $* *(4)$ & $* *(24)$ & $* *(7)$ & & $* *(8)$ \\
\hline
\end{tabular}

*Number of patients with positive MIBI scan

**Number of patients who underwent surgery

Table 3. Patients Satisfying the Items of the 2008 Revised Guideline Criteria

\begin{tabular}{cccc}
\hline Number of items & Men $\mathrm{n}=22$ & Women $\mathrm{n}=65$ & TOTAL $\mathrm{n}=87$ \\
\hline & $\mathrm{n}=6$ & $\mathrm{n}=19$ & $\mathrm{n}=25$ \\
& $*(0)$ & $*(6)$ & $*(6)$ \\
& $* *(0)$ & $* *(4)$ & $* *(4)$ \\
& $\mathrm{n}=14$ & $\mathrm{n}=29$ & $\mathrm{n}=43$ \\
1 & $*(6)$ & $*(12)$ & $*(18)$ \\
& $* *(8)$ & $* *(12)$ & $* *(20)$ \\
& $\mathrm{n}=1$ & $\mathrm{n}=13$ & $\mathrm{n}=14$ \\
2 & $*(1)$ & $*(9)$ & $*(10)$ \\
& $* *(1)$ & $* *(9)$ & $* *(10)$ \\
3 & $\mathrm{n}=1$ & $\mathrm{n}=4$ & $\mathrm{n}=5$ \\
& $*(0)$ & $*(1)$ & $*(1)$ \\
4 & $* *(0)$ & $* *(4)$ & $* *(4)$ \\
5 & $\mathrm{n}=0$ & $\mathrm{n}=0$ & $\mathrm{n}=0$ \\
& $\mathrm{n}=0$ & $\mathrm{n}=0$ & $\mathrm{n}=0$ \\
\hline
\end{tabular}

*Number of patients with postive MIBI scan

**Number of patients who underwent surgery

surgery, while 34 of those meeting at least one surgical criterion selected surgery. The postoperative serum $\mathrm{Ca}$ and PTH levels markedly decreased in all patients who underwent surgery (34 patients with adenoma, two with suspected hyperplasia and two with ectopic adenoma).

Table 1 shows the background characteristics of the analyzed patients; none of the parameters differed significantly between the men and women.

Table 2 shows the results of an analysis of the Workshop guideline criteria for the management of asymptomatic
PHPT proposed in 2008. The patient age was $<50$ years in seven subjects (two men, five women). The Ca level was high (over $11.4 \mathrm{mg} / \mathrm{dL}$ ) in 29 patients (nine men, 20 women). The eGFR was $<60 \mathrm{~mL} / \mathrm{min} / 1.73 \mathrm{~m}^{2}$ in 17 patients (six men, 11 women). The BMD T-score was below $-2.5 \mathrm{SD}$ in 20 patients (all women), and 13 patients had a history of fragility fractures (two men, 11 women). These parameters were further analyzed in relation to the MIBI scintigraphy results. Among the patients with positive MIBI results, three subjects were under 50 years of age (one man, two women), the Ca level was $>11.4 \mathrm{mg} / \mathrm{dL}$ in 17 subjects (five men, 12 women), the eGFR was $<60 \mathrm{~mL} / \mathrm{min} / 1.73 \mathrm{~m}^{2}$ in three subjects (one men, two women), the BMD T-score was below $-2.5 \mathrm{SD}$ in nine subjects (all women) and nine subjects had a history of fracture (one man, eight women). These parameters were additionally analyzed in relation to a history of parathyroid tumor surgery. Among the patients who had undergone surgical resection, four subjects were under 50 years of age (one man, three women), the Ca level was $>11.4 \mathrm{mg} / \mathrm{dL}$ in 24 subjects (six men, 18 women), the eGFR was $<60 \mathrm{~mL} / \mathrm{min} / 1.73 \mathrm{~m}^{2}$ in seven subjects (two men, five women), the BMD T-score was below $-2.5 \mathrm{SD}$ in nine subjects (all women) and eight subjects had a history of fracture (one man, seven women).

The number of Workshop criteria satisfied was then analyzed (Table 3). A total of 25 patients (six men, 19 women) met none of the criteria, 43 patients (14 men, 29 women) satisfied one criterion, 14 patients (one man, 13 women) sat- 
Table 4. Comparison of Positive and Negative MIBI Scans in Each Item

\begin{tabular}{|c|c|c|c|c|c|c|c|c|c|}
\hline & Age (years) & $\begin{array}{l}\text { Serum Ca } \\
(\mathrm{mg} / \mathrm{dL})\end{array}$ & $\begin{array}{c}\text { eGFR } \\
\left(\mathrm{mL} / \mathrm{min} / 1.73 \mathrm{~m}^{2}\right)\end{array}$ & $\begin{array}{l}\text { BMD T-score } \\
(\mathrm{SD})\end{array}$ & $\begin{array}{l}\text { Fracture } \\
\text { History }\end{array}$ & PTH $(\mathrm{pg} / \mathrm{mL})$ & $\begin{array}{l}\text { 24-h urinary } \mathrm{Ca} \\
(\mathrm{mg} / \text { day) }\end{array}$ & ALP (IU/L) & $\operatorname{VitD}(\mathrm{pg} / \mathrm{mL})$ \\
\hline $\begin{array}{l}\text { Men } \\
\text { positive } \\
(\mathrm{n}=7)\end{array}$ & $\begin{array}{l}55.3 \pm 15.5 \\
(\mathrm{n}=7)\end{array}$ & $\begin{array}{l}11.7 \pm 0.8 \\
(n=7)\end{array}$ & $\begin{array}{l}92.5 \pm 21.9 \\
(n=7)\end{array}$ & $\begin{array}{l}-0.3 \pm 0.5 \\
(n=3)\end{array}$ & $\mathrm{n}=1$ & $\begin{array}{l}168.1 \pm 148.4 \\
(n=7)\end{array}$ & $\begin{array}{l}283.0 \pm 73.2 \\
(n=5)\end{array}$ & $\begin{array}{l}412.4 \pm 315.4 \\
(n=7)\end{array}$ & $\begin{array}{l}90.0 \pm 49.6 \\
(n=2)\end{array}$ \\
\hline $\begin{array}{l}\text { negative } \\
(\mathrm{n}=15)\end{array}$ & $\begin{array}{l}64.5 \pm 12.6 \\
(n=15)\end{array}$ & $\begin{array}{l}10.7 \pm 0.9 \\
(n=15)\end{array}$ & $\begin{array}{l}66.6 \pm 22.3 \\
(n=15)\end{array}$ & $\begin{array}{l}0.1 \pm 1.6 \\
(n=12)\end{array}$ & $\mathrm{n}=1$ & $\begin{array}{l}105.3 \pm 53.2 \\
(n=15)\end{array}$ & $\begin{array}{l}161.1 \pm 129.7 \\
(n=10)\end{array}$ & $\begin{array}{l}318.1 \pm 209.9 \\
(n=12)\end{array}$ & $\begin{array}{l}55.2 \pm 20.2 \\
(n=10)\end{array}$ \\
\hline $\begin{array}{l}\text { Women } \\
\text { positive } \\
(\mathrm{n}=28)\end{array}$ & $\begin{array}{l}67.0 \pm 11.1 \\
(n=28)\end{array}$ & $\begin{array}{l}11.4 \pm 1.0 \\
(n=28)\end{array}$ & $\begin{array}{l}89.1 \pm 32.1 \\
(n=28)\end{array}$ & $\begin{array}{l}-2.7 \pm 1.5 \\
(n=19)\end{array}$ & $\mathrm{n}=8$ & $\begin{array}{l}153.9 \pm 112.1 \\
(n=28)\end{array}$ & $\begin{array}{l}275.5 \pm 164.3 \\
(n=19)\end{array}$ & $\begin{array}{l}359.1 \pm 202.9 \\
(n=26)\end{array}$ & $\begin{array}{l}95.3 \pm 34.8 \\
(n=15)\end{array}$ \\
\hline $\begin{array}{l}\text { negative } \\
(n=37)\end{array}$ & $\begin{array}{l}63.7 \pm 10.3 \\
(n=37)\end{array}$ & $\begin{array}{l}10.7 \pm 1.1 \\
(n=37)\end{array}$ & $\begin{array}{l}75.8 \pm 21.5 \\
(n=36)\end{array}$ & $\begin{array}{l}-2.2 \pm 1.1 \\
(n=24)\end{array}$ & $\mathrm{n}=3$ & $\begin{array}{l}133.0 \pm 154.8 \\
(n=37)\end{array}$ & $\begin{array}{l}209.3 \pm 140.1 \\
(n=25)\end{array}$ & $\begin{array}{l}297.2 \pm 188.5 \\
(n=34)\end{array}$ & $\begin{array}{l}62.5 \pm 18.4 \\
(n=24)\end{array}$ \\
\hline $\begin{array}{c}\mathrm{p} \text { value } \\
\text { positive vs. } \\
\text { negative }\end{array}$ & $\mathrm{p}=0.22^{*}$ & $\mathrm{p}=0.013^{*}$ & $\mathrm{p}=0.05^{*}$ & $\mathrm{p}=0.16^{*}$ & $\mathrm{p}=0.046^{* *}$ & $\mathrm{p}=0.54^{*}$ & $\mathrm{p}=0.15^{*}$ & $\mathrm{p}=0.22 *$ & $\mathrm{p}=0.0004^{*}$ \\
\hline $\begin{array}{l}\text { TOTAL } \\
\text { positive } \\
(\mathrm{n}=35)\end{array}$ & $\begin{array}{l}64.7 \pm 12.8 \\
(n=35)\end{array}$ & $\begin{array}{l}11.4 \pm 1.0 \\
(n=35)\end{array}$ & $\begin{array}{l}89.8 \pm 30.0 \\
(n=35)\end{array}$ & $\begin{array}{l}-2.5 \pm 1.6 \\
(n=21)\end{array}$ & $\mathrm{n}=9$ & $\begin{array}{l}156.7 \pm 117.9 \\
(n=35)\end{array}$ & $\begin{array}{l}277.0 \pm 148.6 \\
(n=24)\end{array}$ & $\begin{array}{l}370.4 \pm 226.5 \\
(n=33)\end{array}$ & $\begin{array}{l}94.7 \pm 34.9 \\
(n=17)\end{array}$ \\
\hline $\begin{array}{l}\text { negative } \\
(\mathrm{n}=52)\end{array}$ & $\begin{array}{l}63.9 \pm 10.9 \\
(n=52)\end{array}$ & $\begin{array}{l}10.7 \pm 1.0 \\
(n=52)\end{array}$ & $\begin{array}{l}73.1 \pm 21.9 \\
(n=52)\end{array}$ & $\begin{array}{l}-1.4 \pm 1.7 \\
(n=36)\end{array}$ & $\mathrm{n}=4$ & $\begin{array}{l}105.2 \pm 133.6 \\
(n=52)\end{array}$ & $\begin{array}{l}195.5 \pm 137.1 \\
(n=35)\end{array}$ & $\begin{array}{l}302.7 \pm 192.1 \\
(n=46)\end{array}$ & $\begin{array}{l}60.3 \pm 18.9 \\
(n=34)\end{array}$ \\
\hline $\begin{array}{c}\mathrm{p} \text { value } \\
\text { positive vs. } \\
\text { negative }\end{array}$ & $\mathrm{p}=0.77^{*}$ & $\mathrm{p}=0.0016^{*}$ & $\mathrm{p}=0.0037^{*}$ & $\mathrm{p}=0.021^{*}$ & $\mathrm{p}=0.031 * *$ & $\mathrm{p}=0.25^{*}$ & $\mathrm{p}=0.03 *$ & $\mathrm{p}=0.15^{*}$ & $\mathrm{p}=0.001^{*}$ \\
\hline
\end{tabular}

*: Student's t test.

**: Fisher's exact test

VitD; 1,25 (OH) 2 Vitamin D

isfied two criteria, five patients (one man, four women) satisfied three criteria and no patients met four or more criteria. Among the patients found to be positive on MIBI scintigraphy, six met none of the Workshop criteria (all women), 18 satisfied one criterion (six men, 12 women), 10 satisfied two criteria (one man, nine women) and one satisfied three criteria (a woman). Among the patients who underwent surgical resection of the parathyroid, four satisfied none of the Workshop criteria (all women), 20 satisfied one criterion (eight men, 12 women), 10 satisfied two criteria (one man, nine women) and four (all women) satisfied three criteria.

Each parameter, along with the levels of $\mathrm{PTH}$, daily $\mathrm{Ca}$ excretion, serum ALP and 1,25(OH)2 Vitamin D, was further analyzed in relation to the findings of the MIBI scans using Fisher's exact test for a history of fracture and Student's $t$-test for the other parameters (Table 4). When the entire population was included in the analysis, the levels of $\mathrm{Ca}$, daily $\mathrm{Ca}$ excretion and $1,25(\mathrm{OH}) 2$ Vitamin D were significantly higher in the MIBI-positive group than in the MIBI-negative group, while the BMD T-scores were significantly lower in the positive group. A history of fracture was found to be significantly correlated with a positive MIBI study. The PTH and ALP levels tended to be higher in the MIBI-positive group.

\section{Discussion}

In the past, PHPT could only be diagnosed when the patient presented with marked clinical symptoms (fractures, ureteral stones, etc.), i.e., and thus the diagnosis was made based on these symptoms. For this reason, the incidence of PHPT may have been underestimated. In recent years, however, the percentage of asymptomatic PHPT cases (patients presenting with no clinical symptoms who are diagnosed based on the presence of hypercalcemia or minimal swelling of the parathyroid) among all detected PHPT cases has risen, especially in women (male to female ratio = approximately 1:2) (6). Asymptomatic PHPT is reportedly detected in $2.1 \%$ of all postmenopausal women (7). In this study, of the 87 patients with asymptomatic PHPT, 65 (74.7\%) were women, most of whom were postmenopausal (Table 1). In regards to the number of patients who met each of the Workshop criteria, fewer than $10 \%$ of the patients in men ( $9.1 \%$, two patients) and women $(7.7 \%$, five patients) groups were under 50 years of age. The mean age of the men was $62.0 \pm 14.0$ years, with nine patients in their 50's, five in their 60's, four in their 70's and two in their 80's (data not shown). The mean age of the women was $65.1 \pm 10.7$ years (50's, 16 patients; 60's, 25 patients; 70's, 21 patients; 80's, two patients; data not shown). These results suggest that it is more appropriate the current age criterion be adjusted to 
meet the highest age of individuals requiring intervention in order to reflect the current trend of aging in the Japanese population. The BMD T-score was below $-2.5 \mathrm{SD}$ in 20 women (46.5\% of all women analyzed) and in none of the men. However, 11 women $(16.9 \%)$ and two men $(9.1 \%)$ had a history of fractures. Combining these findings with the increased risk of fracture during daily life in men (8-11), it may be necessary to review the current differences in the BMD T-score levels between men and women. The renal function is prone to compromise in patients with PHPT due to hypercalcemia and the presence of urinary tract stones, and an eGFR of $<60 \mathrm{~mL} / \mathrm{min} / 1.73 \mathrm{~m}^{2}$ (equivalent to $\mathrm{CKD}$ stage III) is one of the criterion included in the guidelines for PHPT management (12-14). In the present study, the mean eGFR was 79.9 $\pm 26.7 \mathrm{~mL} / \mathrm{min}$ (men: 74.9 \pm 24.9 , women: $81.6 \pm 27.3$ ), and the number of patients with an eGFR of $<60 \mathrm{~mL} / \mathrm{min}$ was only 17 (six men and 11 women). Taking these findings together, it is difficult to conclude that the current criterion for eGFR outlined in the PHPT management guidelines is not based on sufficient evidence in Japanese patients, from the viewpoint of preventing further deterioration of the renal function.

In the analysis of the number of parameters met by each patient (Table 3), we found that most patients in each group (14 men and 29 women) satisfied only one criterion, while a relatively large number of patients [six men (27.3\%) and 19 women $(29.2 \%)$ ] satisfied none of the criteria. These findings suggest that it is necessary to examine these parameters, particularly age, the BMD T-score and eGFR, in Japanese patients.

In addition, we analyzed the MIBI scintigraphy findings in relation to each parameter adopted in the guidelines (Table 2, 3). Among the patients found to be positive on MIBI scintigraphy, the rate of MIBI scintigraphy positivity rose as the number of parameters satisfied increased from zero to one and two. Furthermore, when the number of the guideline criteria satisfied was analyzed in relation to surgical treatment, the use of surgical treatment was more common among the patients who met a greater number of the criteria specified in the guidelines. These findings suggest that the number of NIH guideline criteria satisfied may serve as an important indicator and that surgical treatment can be recommended more strongly in patients meeting more of these criteria.

MIBI scintigraphy, the only means of providing functional imaging, is anticipated to play an important role in identifying responsible lesions in these cases (15-17). The sensitivity of MIBI scintigraphy in precisely detecting parathyroid lesions varies considerably (34-100\%) among reports (18). Some of the factors possibly affecting the sensitivity of MIBI scintigraphy, as indicated in past reports, include the serum Ca level, PTH level, vitamin D level, size and weight of the lesion, type of cells constituting the lesion (chief cells, eosinophilic cells), accompanying thyroid lesions and others. However, the extent to which these factors actually affect the capability of MIBI scintigraphy to detect lesions has not yet been fully clarified.

With this in mind, the MIBI scintigraphy findings (positive/negative) were analyzed in relation to each parameter included in the guidelines in addition to other parameters (the levels of PTH, daily urinary $\mathrm{Ca}$ excretion, ALP and 1,25(OH)2 Vitamin D) (Table 4). When the entire population was included in the analysis, these findings indicated a correlation between the criteria and the results of MIBI scintigraphy and that the levels of PTH, daily urinary Ca excretion, ALP and 1,25(OH)2 Vitamin D, which are not adopted in the current guidelines, can serve as potent indicators to determine the strategy for treating PHPT.

In this study (Figure), three patients who were found to be positive on MIBI scintigraphy satisfied none of the NIH guideline criteria but requested surgical treatment of parathyroid adenomas detected on both MIBI scintigraphy and ultrasonography. All pathological findings were consistent with adenoma, and the serum $\mathrm{Ca}$ and PTH levels normalized postoperatively. The Workshop guidelines state that imaging studies are not appropriate for confirming the diagnosis of PHPT or screening patients for surgical referral and that negative imaging findings should not preclude surgical referral or intervention. However, it is desirable to enforce the use of MIBI scintigraphy whenever possible because the localized diagnosis that can be achieved with this modality decreases the risk of surgical invasiveness, thereby increasing the operative success rate (19). The use of MIBI scintigraphy is advocated for determining whether surgery is indicated, even if the guideline criteria are not met.

Concerning the management of asymptomatic PHPT, it is evident that, in a certain percentage of patients, providing follow-up without surgery, i.e., selecting medical treatment, is safer and more beneficial (20). However, judging from the evidence collected to date $(15,21,22)$, it is advisable to recommend surgical treatment for patients with asymptomatic PHPT. Few reports have so far discussed the guidelines for daily examinations of actual patients with asymptomatic PHPT in reference to imaging examinations, as evaluated in the current study. Rubin et al. (23) performed resection in 50 of 99 patients with asymptomatic PHPT and followed the subjects for a maximum of 15 years, reporting that the disease progressed in $37 \%$ of patients not treated surgically. Fang et al. (19) performed resection in 19 of 33 PHPT patients with a high risk for surgery and provided medical treatment to 14 who refused surgery. The patients were followed for two to three years, with significant disease exacerbation observed in the non-surgically treated patients. In Japan, Sakuta et al. (24) reported that 48 of 67 patients with PHPT underwent resection, while 19 were followed up with conservative management. In the present study (Figure), 33 patients found to be negative on MIBI satisfied at least one of the guideline criteria. A total of 24 patients of these patients were managed without surgical treatment due to an advanced age, complications or refusal of surgery. Among 29 patients found to be positive on MIBI who satisfied at least one of the guideline criteria, four were managed with- 
out surgery due to their refusal of surgical treatment. Meanwhile, a limitation of this study is the lack of data regarding the long-term natural history of asymptomatic PHPT with or without parathyroid surgery. A further limitation is that this study was neither randomized nor controlled. Nonetheless, according to our results, therapeutic methods were selected based on the criteria in the guidelines, the results of imaging diagnosis and patient preferences in Japanese patients with asymptomatic PHPT in the actual clinical setting. Furthermore, taking into account the postoperative $\mathrm{Ca}$ and PTH values and pathological results, this study offers valuable insight with respect to the clinical management of asymptomatic PHPT.

An additional limitation is that our results were obtained using an observational study conducted at one institution. As there may be bias in the selection of therapeutic methods specific to our department, it is necessary to examine the results of widely performed studies, including those performed at other institutions. The present investigation was conducted as a pilot study to analyze each parameter adopted in the Workshop guidelines for the management of asymptomatic PHPT proposed in 2008 among 87 patients with asymptomatic PHPT who underwent MIBI scintigraphy at our center. It is desirable that further evidence be collected and that the current criteria be reviewed when applied to Japanese patients.

The authors state that they have no Conflict of Interest (COI).

\section{References}

1. Potts JT. Management of asymptomatic hyperparathyroidism. J Clin Endocrinol Metab 70: 1489-1493, 1990.

2. Bilezikian JP, Potts JT, Fuleihan Gel-H, et al. Summary statement from workshop on asymptomatic primary hyperparathyroidism: a perspective for the 21st century. J Clin Endocrinol Metab 87: 5353-5361, 2002.

3. Khan AA, Bilezikian JP, Potts JT Jr. The diagnosis and management of asymptomatic primary hyperparathyroidism revisited. J Clin Endocrinol Metab 94: 333-334, 2009.

4. Bilezikian JP, Khan AA, Potts JT Jr. Guidelines for the management of asymptomatic primary hyperparathyroidism: summary statement from the third international workshop. J Clin Endocrinol Metab 94: 335-339, 2009.

5. Marcocci C, Cetani F. Primary hyperparathyroidism. N Engl J Med 365: 2389-2397, 2011.

6. Wermers RA, Khosla S, Atkinson EJ, et al. Incidence of primary hyperparathyroidism in Rochester, Minnesota, 1993-2001: an update on the changing epidemiology of the disease. J Bone Miner Res 21: 171-177, 2006

7. Lundgren E, Rastad J, Åkerström G, Ljunghall S. Population based case-control study of sick leave in postmenopausal women before diagnosis of hyperparathyroidism. Surgery 121: 287-294, 1997.
8. Abbas JS, Hashem SI, Faraj WG, Khalifeh MJ, Horani MH, Salti IS. The outcome of cervical exploration for asymptomatic and symptomatic patients with primary hyperparathyroidism. World J Surg 30: 69-75, 2006.

9. Hagstrom E, Lundgren E, Mallmin H, Rastad J, Hellman P. Positive effect of parathyroidectomy on bone mineral density in mild asymptomatic primary hyperparathyroidism. J Intern Med 259: 191-198, 2006.

10. Mosekilde L. Primary hyperparathyroidism and the skeleton. Clin Endocrinol 69: 1-19, 2008.

11. Silverberg SJ, Lewiecki EM, Mosekilde L, Peacock M, Rubin MR. Presentation of asymptomatic primary hyperparathyroidism: proceedings of the Third International Workshop. J Clin Endocrinol Metab 94: 351-365, 2009.

12. Frøkjaer VG, Mollerup CL. Primary hyperparathyroidism: renal calcium excretion in patients with and without renal stone sisease before and after parathyroidectomy. World J Surg 26: 532-535, 2002.

13. Odvina CV, Sakhaee K, Heller HJ, et al. Biochemical characterization of primary hyperparathyroidism with and without kidney stones. Urol Res 35: 123-128, 2007.

14. Bouzidi H, Brauwere D, Daudon M. Does urinary stone composition and morphology help for prediction of primary hyperparathyroidism? Nephral Dial Transplant 26: 565-572, 2011.

15. Goldstein RE, Blevins L, Delbeke D, Martin WH. Effect of minimally invasive radioguided parathyroidectomy on efficacy, length of stay, and costs in the management of primary hyperparathyroidism. Ann Surg 231: 732-742, 2000.

16. Fraker DL, Harsono H, Lewis R. Minimally invasive parathyroidectomy: benefits and requirements of localization, diagnosis, and intraoperative PTH monitoring. Long-term results. World J Surg 33: 2256-2265, 2009.

17. Udelsman R, Pasieka JL, Sturgeon C, Young JEM, Clark OH. Surgery for asymptomatic primary hyperparathyroidism: proceedings of the Third International Workshop. J Clin Endocrinol Metab 94: 366-372, 2009

18. Mihai R, Simon D, Hellman P. Imaging for primary hyperparathyroidism: an evidence-based analysis. Langenbecks Arch Surg 394: 765-784, 2009.

19. Fang WL, Tseng LM, Chen JY, et al. The management of highrisk patients with primary hyperparathyroidism: minimally invasive parathyroidectomy vs. medical treatment. Clin Endocrinol 68: 520-528, 2008.

20. Khan A, Grey A, Shoback D. Medical management of asymptomatic primary hyperparathyroidism: proceedings of the Third International Workshop. J Clin Endocrinol Metab 94: 373-381, 2009.

21. Silverberg SJ, Shane E, Jacobs TP, Siris E, Bilezikian JP. A 10year prospective study of primary hyperparathyroidism with or without parathyroid surgery. N Engl J Med 341: 1249-1255, 1999.

22. Caron NR, Pasieka JL. What symptom improvement can be expected after operation for primary hyperparathyroidism? World J Surg 33: 2244-2255, 2009.

23. Rubin MR, Bilezikian JP, McMahon DJ, et al. The natural history of primary hyperparathyroidism with or without parathyroid surgery after 15 years. J Clin Endocrinol Metab 93: 3462-3470, 2008.

24. Sakuta A, Iijima T, Domeki $\mathrm{N}$, et al. The etiology, clinical features aand management of hypercaicemia and its crisis. Dokkyo Igakkai Zasshi (Dokkyo J Med Sci) 39: 45-55, 2012 (in Japanese, Abstract in English).

(C) 2014 The Japanese Society of Internal Medicine http://www.naika.or.jp/imonline/index.html 